\section{Effect on Crop Growth of Rain after Prolonged Drought}

AN investigation of the effect of irrigation on the growth of the sugar beet crop was started in 1955 at Woburn, Beds. Measurements of dry weight and leaf area were made on samples of the crop taken from twelve plots, six of which were irrigated. The experiment also included a comparison of two rates of nitrogen supply, but for the present purpose this can be ignored; the results in Table 1 are means for the two rates. Material was available for sampling on only three occasions, as most of the crop had to be kept for measurement of yield at the normal time of harvest.

Table 1. EFFect of IrRIgation ON DRY-MATTER YIeld AND LEAFARRA INDEX OF A SUGAR BEET CROP ON (1) JULY 27, (2) AUGUST 10 AND (3) AUGUST 24, 1955, AND ON NET ASSIMILATION RATE, RELATIVI LEAF-GROWTH RATE, AND THE INCREMENT OF DRY-WEIGHT YIELD

\begin{tabular}{|c|c|c|c|c|c|c|}
\hline \multirow{3}{*}{$\begin{array}{l}\quad \text { Time } \\
\text { Irrigated } \\
\text { Not irrigated } \\
\text { S.E. }\end{array}$} & \multicolumn{3}{|c|}{ Dry weight (gm./m. $\left.{ }^{2}\right)$} & \multicolumn{3}{|c|}{ Leaf-area index } \\
\hline & $\begin{array}{r}1 \\
226 \\
187 \\
14\end{array}$ & $\begin{array}{c}2 \\
531 \\
300 \\
36\end{array}$ & $\begin{array}{c}3 \\
704 \\
544 \\
56\end{array}$ & $\begin{array}{c}1 \\
1 \cdot 43 \\
1 \cdot 03 \\
0 \cdot 08\end{array}$ & $\begin{array}{c}2 \\
2 \cdot 35 \\
1 \cdot 04 \\
0 \cdot 12\end{array}$ & $\begin{array}{c}3 \\
2 \cdot 60 \\
1 \cdot 62 \\
0 \cdot 17\end{array}$ \\
\hline & \multicolumn{2}{|c|}{$\begin{array}{l}\text { Net assimila- } \\
\text { tion rate } \\
\left.\text { (gm./m. }{ }^{2} / \text { week }\right)\end{array}$} & \multicolumn{2}{|c|}{$\begin{array}{c}\text { Relative leaf- } \\
\text { growth rate } \\
\text { (per cent per week) }\end{array}$} & \multicolumn{2}{|c|}{$\begin{array}{l}\text { Dry-weight } \\
\text { increment } \\
\left(\mathrm{gm} . / \mathrm{m}^{2}{ }^{2}\right)\end{array}$} \\
\hline $\begin{array}{l}\quad \text { Interval } \\
\text { Irrigated } \\
\text { Not irrigated } \\
\text { S.E. }\end{array}$ & $\begin{array}{c}1-2 \\
83 \\
53 \\
8\end{array}$ & $\begin{array}{c}2-3 \\
34 \\
96 \\
14\end{array}$ & $\begin{array}{c}1-2 \\
26 \\
0 \\
3\end{array}$ & $\begin{array}{r}2-3 \\
5 \\
20 \\
6\end{array}$ & $\begin{array}{r}1-2 \\
305 \\
113 \\
30\end{array}$ & $\begin{array}{r}2-3 \\
173 \\
244 \\
59\end{array}$ \\
\hline
\end{tabular}

No rain had fallen for three weeks before the first sampling on July 27, and the estimated water deficit on the unirrigated plots was then 4 in. On the irrigated plots it was kept below 1 in. by appropriate irrigation throughout the growth period. The dry. woight yield and leaf-area index ( $L$, ratio of leaf area to land area) of the irrigated crop (Table l) were already much greater than those of the unirrigated crop. There was no rain in the following fortnight, and at the second sampling on August 10 the estimated water deficit on the unirrigated plots had increased to 5 in.; the effect of irrigation on dryweight yield had also greatly increased. The net assimilation rate $(E)$ of the irrigated plants in the interval between July 27 and August 10 was sig. nificantly greater than that of the unirrigated plants. On the unirrigated plots, $L$ did not increase during the interval, but it increased so much on the irrigated plots that on August 10 it was more than doubled by irrigation. Because of the large effects on both $E$ and $L$, the increment of dry-matter yield between July 27 and August 10 was nearly trebled by irrigation.

During the next two weeks, $0 \cdot 6$ in. of rain fell, but in spite of this the estimated water deficit of the unirrigated land had increased to nearly 6 in. on August 24. For the irrigated plants, $E$ was less than in the previous period, presumably because of changes in environmental factors other than water supply, but for the unirrigated plants it was greater than before. Consequently, in the second period the effect of irrigation was reversed and $E$ was nearly three times as great for the unirrigated as for the irrigated plants. During the second period also, $L$ increased more, both absolutely and relatively, on the unirrigated plots, but on August 2s it was still much smaller than on the irrigated plots. However, $E$ was so much greater for the unirrigated plots that in spite of $L$ being smaller the increment of dry-matter yield was larger, though not significantly, than on the irrigated plots.
These results show that, after prolonged drought, rainfall in amounts very small compared with the soil-moisture deficit, and therefore with amounts used in orthodox irrigation practice, caused such large increases both in leaf growth and in the rate of photosynthesis of unirrigated plants that, temporarily, these plants grew faster than irrigated ones that had never been subjected to severe water stress. It is intended to repeat this work (though the same conditions may not recur in the field in 1956) and, if possible, to imitate the conditions of water supply in laboratory experiments. If the results are confirmed, they may have an important bearing on the efficient use of irrigation water.

$$
\begin{aligned}
& \text { P. C. OWEN } \\
& \text { D. J. WATSON }
\end{aligned}
$$

Rothamsted Experimental Station. Harpenden, Herts. Feb. 28.

\section{Polymorphism and Parthenogenesis in a Ptinid Beetle}

Ptinus latro Fab. (1775) and $P$. hirtellus Sturm (1837) (Coleoptera, Ptinidae) have for long been accepted as separate, sexually dimorphic species. The females of the two forms are abundantly distinct, but no satisfactory separation character for males has ever been described (see Hinton's monograph ${ }^{1}$ ).

$P$. hirtellus has been maintained in culture at the Pest Infestation Laboratory for many generations and abundant material of both sexes has been available for study. Attempts to obtain cultures of $P$. latro by similar methods have led to the discovery that this is a parthenogenetic form of unusual type.

Through the kind co-operation of the London area inspectors of the Ministry of Agriculture, Fisheries and Food, a few living female latro were obtained during November 1953. These were cultured on a mixture of equal parts of fishmeal and wheatmeal with about 5 per cent dried yeast, at $25^{\circ} \mathrm{C}$. and 70 per cent relative humidity, and eventually seventeen larvæ were obtained. From these, seventeen adults were reared, all of which proved to be female latro. They were separated into two groups of seven and ten individuals, respectively. The former were kept unmated until death (a matter of several months), whereas the latter were provided with twelve fresh males from a culture of hirtellus. No progeny resulted from the virgin females, but the mated females produced twenty-one larvæ. Again exclusively female latro were reared.

On the advice of $\mathrm{Mr}$. R. W. Howe, of the Pest Infestation Laboratory, the third generation was cultured (with hirtellus males) at $20^{\circ} \mathrm{C}$, a temperature which he has found to be the optimal for oviposition in several species of ptinids. This resulted in a very large culture, and between 1,500 and 2,000 adults, all female latro, were reared. Many thriving cultures are now being maintained under these conditions, but further experiments with virgin females have again failed.

The biological findings strongly suggest that female latro reproduce by parthenogenesis, and this is supported by the extreme uniformity of the reared individuals. However, mating, which takes place very readily with male hirtellus, appears to be essential, for we have never succeeded in rearing from virgin latro. Under crowded conditions, unmated females will lay a fow eggs, but these do not hatch 